\title{
Prevalence and determinants of stunting and overweight in 3-year-old black South African children residing in the Central Region of Limpopo Province, South Africa
}

\author{
Ramoteme L Mamabolo ${ }^{1,2, *}$, Marianne Alberts ${ }^{1}$, Nelia P Steyn ${ }^{2}$, \\ Henriette A Delemarre-van de $\mathrm{Waal}^{3}$ and Naomi S Levitt ${ }^{4}$ \\ ${ }^{1}$ Medical Sciences Programme, University of Limpopo, Sovenga, South Africa: ${ }^{2}$ Chronic Diseases of Lifestyle Unit, \\ Medical Research Council, PO Box 19070, Tygerberg, Cape Town 7505, South Africa: ${ }^{3}$ Pediatric Endocrinology, \\ Vrije University Medical Centre, Vrije University, Amsterdam, The Netherlands: ${ }^{4}$ Department of Medicine, \\ University of Cape Town, Cape Town, South Africa
}

Submitted 15 March 2005: Accepted 6 June 2005

\begin{abstract}
Objectives: To determine the prevalence of stunting, wasting and overweight and their determinants in 3-year-old children in the Central Region of Limpopo Province, South Africa.

Design: Prospective cohort study.

Setting: Rural villages in the Central Region of the Limpopo Province, South Africa. Subjects: One hundred and sixty-two children who were followed from birth were included in the study. Anthropometric measurements and sociodemographic characteristics of the children were recorded.

Results: Height-for-age $Z$-scores were low, with a high prevalence of stunting (48\%). The children also exhibited a high prevalence of overweight (22\%) and obesity (24\%). Thirty-one (19\%) children were both stunted and overweight. Gaining more weight within the first year of life increased the risk of being overweight at 3 years by 2.39 times (95\% confidence interval (CI) 1.96-4.18) while having a greater length at 1 year was protective against stunting (odds ratio (OR) $0.41 ; 95 \%$ CI $0.17-0.97$ ). Having a mother as a student increased the risk for stunting at 3 years by 18.21 times ( $95 \%$ CI 9.46-34.74) while having a working mother increased the risk for overweight by 17.87 times (95\% CI 8.24-38.78). All these factors also appeared as risks or as being protective in children who were both overweight and stunted, as did living in a household having nine or more persons (OR 5.72; 95\% CI 2.7-12.10).

Conclusion: The results of this study highlight the importance of evaluating anthropometric status in terms of both stunting and overweight. Furthermore, it is important to realise the importance of normal length and weight being attained at 1 year of age, since these in turn predict nutritional status at 3 years of age.
\end{abstract}

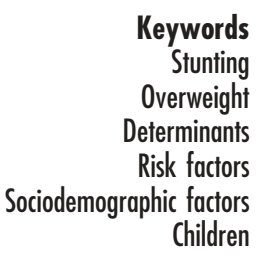

The nutritional transition, i.e. the major change in the nutritional profile of human populations resulting from a shift from a traditional diet to a Western one, is determined by the interplay of economic, demographic, environmental and cultural changes occurring in a society and plays a role in the prediction and determination of the nutritional status of the overall population ${ }^{1-3}$.

Children's physical growth patterns are among the tools used to assess a population's nutritional status. Physical growth itself is regulated by two major factors: genetics and the environment ${ }^{4,5}$. Although the quantity and quality of food are the main environmental determinants of good nutritional status, children's physical and psychosocial surroundings also impact on their growth.

Stunting (i.e. linear growth faltering) is an important public health problem for children living in environments with poverty, poor nutrition and high prevalences of infectious diseases such as found in developing countries ${ }^{4,6}$. Socio-economic status such as the mother's education and occupation, household income and health expenditure may influence stunting levels indirectly ${ }^{7-9}$, whilst a number of factors may be directly causative, including micronutrient deficiencies, inadequate protein intake, intrauterine malnutrition, maternal stature and infections $s^{5,10}$.

In Africa as a whole, and in Sub-Saharan Africa, 35\% and $42 \%$ respectively of children under 5 years of age are believed to be stunted ${ }^{11,12}$. In South Africa, a greater proportion of younger children are stunted (21-48\%) rather than underweight $(8-15 \%)^{13-16}$. Experience has shown that these chronically malnourished children are susceptible to increased morbidity and mortality, and are the most vulnerable group in communities. Endemic 
poverty (as evidenced by poor education, unemployment and increased household density) and lack of basic resources for nutritional well-being form the basis for poor nutritional status in these children ${ }^{16-19}$.

It is now also recognised that, in addition to undernutrition in children and pregnant mothers, the nutrition transition has led to an increase in overweight and obesity in the adult population resulting in an increase in the prevalence of chronic diseases ${ }^{20}$. In recent years, however, this phenomenon has filtered down to the child population of South Africa and other developing countries undergoing the transition ${ }^{13,14,16,21,22}$. The National Food Consumption Survey in South African children between 1 and 9 years of age reported that the prevalence of combined overweight and obesity at the national level was as high as that for stunting, namely 17.1 and $19.3 \%$, respectively ${ }^{16}$. The present study aimed at determining the prevalence and determinants of stunting and overweight in 3-year-old children residing in a semi-rural area in South Africa.

\section{Methods}

\section{Study area and subjects}

The study took place in villages in the Central Region of Limpopo Province, which is to the north of South Africa. These villages are typical of those found in rural areas of the country. They are characterised by poor infrastructure and very high levels of unemployment, reflecting a transition between traditional and modern lifestyles since many of the younger adults work in neighbouring towns and cities and return home for periodic visits.

The study participants were infants born to women who were recruited while attending prenatal clinics at nine randomly selected local clinics during their third trimester. Of the 219 infant participants, 162 could be traced at 3 years of age ( $74 \%$ response rate). The fall in number at follow-up was largely due to migration both within the studied villages as well as to outside the study area. The lack of proper addresses, formal streets and roads in these villages impeded the process of tracing the mothers and their infants, especially during the early phases of the study.

At the age of 3 years or within one month thereof, trained fieldworkers interviewed the caregivers of the remaining participants and examined the children's anthropometric status. The results used herein also involved those collected in the earlier phases of the study, some of which have been published elsewhere ${ }^{15,23}$.

\section{Anthropometric measurements}

Birth anthropometric measurements were taken from hospital records. The children's weight, height, head circumference, mid-arm circumference and abdominal circumference were measured. Weight was measured with a baby scale (TANITA Baby Scale, model 1380; Tanita Corporation, Tokyo, Japan) to the nearest $0.1 \mathrm{~kg}$; height was measured with a non-stretchable tape measure mounted on a board to the nearest $0.5 \mathrm{~cm}$, with the child standing on a flat surface against the wall.

The World Health Organization recommends the United States' National Center for Health Statistics percentiles as a reference for international use ${ }^{24}$. Following conventional cut-off points of $Z$-scores, malnutrition in its various forms is defined as follows:

- Stunting - height-for-age Z-score (HAZ) below the median by more than minus two standard deviations $(<-2 \mathrm{SD})$.

- Wasting - weight-for-height $Z$-score (WHZ) below the median by $<-2$ SD.

- Underweight - weight-for-age $Z$-score (WAZ) below the median by $<-2 \mathrm{SD}$.

- Overweight - either body mass index (BMI) above the age-specific reference values recommended by the International Obesity Task Force $(\mathrm{IOTF})^{25}$ or WHZ above the median by $>1$ SD.

- Obesity - either BMI above the age-specific reference values recommended by the IOTF $^{25}$ or WHZ above the median by $>2 S D$.

Changes in SD scores between birth and 1 year, 1 and 3 years, and birth and 3 years were calculated. A gain in weight or length/height SD score between birth and 1 year of 0.67SD was taken to indicate clinically significant catchup growth; similarly, a decrease in SD score by $<-0.67$ SD indicated catch-down growth ${ }^{26}$.

\section{Assessment of sociodemographic factors}

The sociodemographic status of households and factors related to the health of infants were assessed by use of a structured questionnaire developed by the authors ${ }^{23}$. The following were included: the mother's educational status, occupation, marital status, age and parity, and infant's age of weaning. The housing structures were divided into three categories: traditional mud houses, brick houses and shacks (made of corrugated iron and timber). Overcrowding was assessed by determining the total number of persons in the household and the number of children less than 5 years of age.

\section{Ethical approval}

The University of Limpopo Ethics Committee and the Limpopo Province Department of Health Research Committee approved the study. The aim and objectives of the study, as well as a detailed explanation of the procedures to be employed, were explained to the mother/caregiver of the selected child both verbally and in the form of an information sheet. Informed oral consent was obtained from the child's mother/caregiver prior to the measurements.

\section{Statistical analysis}

Statistical analyses were done using two statistical packages: Epi-Info $2002^{27}$ and SPSS $12.0^{28}$. Statistical 
significance was set at $P<0.05$. Student's $t$-test was used for comparison between means, the chi-square test for comparison between proportions in the various subgroups, and Pearson's correlations to measure the association between two continuous variables. Binary logistic regression was used to assess the risk factors for both stunting and overweight. To take care of any spillover effect that might have resulted from children being both stunted and overweight, a third group consisting of these children was created. The infants were thus divided into four groups: neither stunted nor overweight, stunted, overweight, and both stunted and overweight. Based on these, multinomial regression analysis was conducted to examine factors associated with the various nutritional states with reference to the normal children. Only factors that were significant in the binary logistic regression were entered into the model.

\section{Results}

Of the 162 children who attended the follow-up at 3 years, $48 \%$ were stunted, $9 \%$ were underweight, $1 \%$ were wasted, $18 \%$ were overweight and $24 \%$ were obese (Table 1). The physical characteristics of the children according to their nutritional status, i.e. those who were stunted and those who were overweight, are presented in Table 2.

\section{Sociodemographic characteristics}

Overall $85 \%$ of the children were from families with more than five people per household, 21\% already had younger siblings, 19\% were from families with three or more children below the age of 5 years, and a large proportion (71\%) were breast-fed for 12 months or more. Most of the mothers were still single (61\%) and $88 \%$ of them had secondary education or higher. Ninety per cent of the children saw their mothers on a daily basis, but $67 \%$ did not live in the same household as their fathers. The level of unemployment in the mothers was high
(67\%). Consequently, the mother was the primary caregiver for the majority of the children (74\%). Twenty-six per cent of the children lived in either traditional houses or shacks.

\section{Stunting in the children}

A higher proportion of stunted children were underweight than non-stunted children (17\% vs. 2\%) (Table 1). In both groups the prevalence of obesity was high (26\% and $21 \%$, respectively).

Stunted 3-year-old children lived in households having a larger number of people $(P=0.008)$ and more children below 5 years of age $(P=0.038)$ than non-stunted children. In addition, the mothers of stunted children were significantly shorter than the mothers of non-stunted children $(P=0.006)$. Of the anthropometric measurements only head circumference did not differ between these two groups (Table 2).

Compared with non-stunted children, a greater proportion of stunted children were already stunted (49\% vs. $22 \% ; P=0.001)$ and wasted (22\% vs. $3 \% ; P=0.001$ ) at 1 year of age; came from families with a large number of people per household ( $33 \%$ vs. $19 \% ; P=0.017$ ); already had younger siblings ( $27 \%$ vs. $17 \% ; P=0.064$ ); came from households with more children below the age of 5 years ( $27 \%$ vs. $12 \%$; $P=0.007)$; had mothers with a primary education (15\% vs. $8 \% ; P=0.132)$; had mothers who were still students (19\% vs. $11 \% ; P=0.124)$; were more often cared for by their grandmothers (26\% vs. $12 \% ; P=0.014)$; and more frequently lived in shacks ( $21 \%$ vs. $12 \% ; P=0.076$ ).

Table 3 shows the results of the binary logistic regression in the stunted as well as the overweight children. In the stunted children, living in a household with nine or more individuals increased the risk of being stunted eight-fold while having a mother who was a student increased this almost four-fold. Protective factors against stunting were found to be attaining a greater length and having an increased Ponderal Index by 1 year.

Table 1 Prevalence $(n, \%)$ of different nutritional states in stunted and non-stunted 3-year-old children

\begin{tabular}{|c|c|c|c|c|c|}
\hline & & Total $(n=162)$ & Stunted $(n=78)$ & Normal $(n=84)$ & $P$-value \\
\hline \multicolumn{6}{|l|}{ HAZ } \\
\hline$-2 S D$ to $2 S D$ & Stunted & $78(48)$ & & & \\
\hline$<-2 S D$ & Normal & 84 (52) & & & \\
\hline WAZ & & & & & $<0.0001$ \\
\hline$<-2 S D$ & Under weight & $15(9)$ & $13(17)$ & $2(2)$ & \\
\hline$-2 S D$ to $2 S D$ & Normal & $139(86)$ & $65(83)$ & $74(88)$ & \\
\hline$>2 S D$ & Over weight & $8(5)$ & $0(0)$ & $8(10)$ & \\
\hline WHZ & & & & & 0.327 \\
\hline$<-2 S D$ & Wasted & $1(1)$ & $1(1)$ & $0(0)$ & \\
\hline$-2 S D$ to $2 S D$ & Normal & $132(81)$ & $61(78)$ & $71(85)$ & \\
\hline$>2 S D$ & Over weight & $29(18)$ & $16(21)$ & $13(15)$ & \\
\hline BMI & & & & & 0.057 \\
\hline $19.0-24.9 \mathrm{~kg} \mathrm{~m}^{-2}$ & Normal & $88(54)$ & $47(60)$ & $41(49)$ & \\
\hline $25.0-29.9 \mathrm{~kg} \mathrm{~m}^{-2}$ & Over weight & $36(22)$ & $11(14)$ & $25(30)$ & \\
\hline$\geq 30 \mathrm{~kg} \mathrm{~m}^{-2}$ & Obese & $38(24)$ & $20(26)$ & $18(21)$ & \\
\hline
\end{tabular}

HAZ - height-for-age Z-score; SD - standard deviation; WAZ - weight-for-age Z-score; WHZ - weight-for-height Z-score; $\mathrm{BMI}$ - body mass index (based on sex-specific percentile crossing at 18 years). 
Table 2 Maternal and household characteristics and anthropometric measurements (mean \pm standard deviation) of the total study population, the stunted and the overweight children

\begin{tabular}{|c|c|c|c|c|c|c|c|}
\hline & $\begin{array}{c}\text { Total } \\
(n=162)\end{array}$ & $\begin{array}{l}\text { Stunted } \\
(n=78)\end{array}$ & $\begin{array}{c}\text { Non-stunted } \\
\quad(n=84)\end{array}$ & $P$-value* & $\begin{array}{l}\text { Overweight and } \\
\text { obese }(n=74)\end{array}$ & $\begin{array}{l}\text { Normal weight } \\
\quad(n=88)\end{array}$ & $P$-value* \\
\hline \multicolumn{8}{|l|}{ Maternal and household characteristics } \\
\hline No. in household & $7.1 \pm 2.7$ & $7.7 \pm 2.9$ & $6.6 \pm 2.3$ & 0.008 & $7.6 \pm 2.8$ & $6.7 \pm 2.5$ & 0.044 \\
\hline No. of children aged $<5$ years & $1.7 \pm 0.9$ & $1.9 \pm 1.1$ & $1.6 \pm 0.8$ & 0.038 & $1.6 \pm 0.9$ & $1.8 \pm 2.0$ & 0.226 \\
\hline Time of weaning from breast (months) & $14.9 \pm 8.2$ & $14.7 \pm 8.4$ & $15.2 \pm 8.0$ & 0.720 & $15.3 \pm 8.1$ & $14.6 \pm 8.3$ & 0.618 \\
\hline Maternal age (years) & $25.5 \pm 6.9$ & $26.4 \pm 7.5$ & $25.8 \pm 7.4$ & 0.633 & $25.1 \pm 7.1$ & $26.8 \pm 7.6$ & 0.148 \\
\hline Maternal height $(\mathrm{m})$ & $1.6 \pm 0.7$ & $1.5 \pm 0.1$ & $1.6 \pm 0.1$ & 0.006 & $1.6 \pm 0.1$ & $1.6 \pm 0.1$ & 0.212 \\
\hline Parity & $2.8 \pm 2.1$ & $2.9 \pm 2.1$ & $2.7 \pm 2.2$ & 0.464 & $2.6 \pm 2.1$ & $3.0 \pm 2.2$ & 0.249 \\
\hline \multicolumn{8}{|l|}{ Child measurements } \\
\hline Birth weight (kg) & $3.1 \pm 0.6$ & $3.1 \pm 0.6$ & $3.2 \pm 0.6$ & 0.362 & $3.3 \pm 0.5$ & $3.0 \pm 0.6$ & 0.017 \\
\hline Birth length (cm) & $49.3 \pm 2.6$ & $48.9 \pm 2.5$ & $49.5 \pm 2.6$ & 0.210 & $49.7 \pm 2.1$ & $48.9 \pm 2.8$ & 0.108 \\
\hline Birth Ponderal Index $\left(\mathrm{kg} \mathrm{m}^{-3}\right)$ & $26.3 \pm 4.5$ & $26.4 \pm 4.5$ & $26.2 \pm 4.4$ & 0.841 & $26.5 \pm 4.6$ & $26.1 \pm 4.3$ & 0.616 \\
\hline 1-year weight $(\mathrm{kg})$ & $9.4 \pm 1.4$ & $8.9 \pm 1.4$ & $9.8 \pm 1.4$ & $<0.0001$ & $9.9 \pm 1.4$ & $8.9 \pm 1.3$ & $<0.0001$ \\
\hline 1-year length $(\mathrm{cm})$ & $72.1 \pm 4.0$ & $70.9 \pm 3.5$ & $73.4 \pm 4.0$ & $<0.0001$ & $73.1 \pm 3.4$ & $71.3 \pm 4.2$ & 0.010 \\
\hline 1-year Ponderal Index $\left(\mathrm{kg} \mathrm{m}^{-3}\right)$ & $24.8 \pm 4.1$ & $24.6 \pm 4.4$ & $25.1 \pm 3.8$ & 0.561 & $25.3 \pm 2.7$ & $24.5 \pm 5.0$ & 0.237 \\
\hline 3-year weight $(\mathrm{kg})$ & $13.8 \pm 2.0$ & $12.7 \pm 1.5$ & $14.8 \pm 1.8$ & $<0.0001$ & $15.2 \pm 1.7$ & $12.6 \pm 1.3$ & $<0.0001$ \\
\hline 3-year length (cm) & $87.5 \pm 4.2$ & $84.2 \pm 2.7$ & $90.7 \pm 2.6$ & $<0.0001$ & $87.6 \pm 4.5$ & $87.5 \pm 3.9$ & 0.915 \\
\hline 3-year head circumference $(\mathrm{cm})$ & $50.55 \pm 3.3$ & $50.48 \pm 4.5$ & $50.63 \pm 1.3$ & 0.777 & $51.69 \pm 4.2$ & $49.59 \pm 1.83$ & $<0.0001$ \\
\hline 3-year mid-arm circumference (cm) & $16.46 \pm 1.3$ & $16.08 \pm 1.4$ & $16.81 \pm 1.0$ & $<0.0001$ & $17.16 \pm 1.1$ & $15.87 \pm 1.07$ & $<0.0001$ \\
\hline 3-year abdominal circumference $(\mathrm{cm})$ & $49.83 \pm 3.3$ & $48.74 \pm 3.3$ & $50.84 \pm 3.0$ & $<0.0001$ & $51.70 \pm 3.0$ & $48.26 \pm 2.66$ & $<0.0001$ \\
\hline BMI $\left(\mathrm{kg} \mathrm{m}^{-1}\right)$ at 3 years & $18.0 \pm 2.3$ & $17.9 \pm 2.2$ & $18.1 \pm 2.4$ & 0.836 & $19.9 \pm 1.9$ & $16.5 \pm 1.0$ & $<0.0001$ \\
\hline $\mathrm{HAZ}$ at 3 years & $-2.0 \pm 1.1$ & $-2.9 \pm 0.7$ & $-1.2 \pm 0.6$ & $<0.0001$ & $-2.0 \pm 1.1$ & $-2.0 \pm 1.0$ & 0.958 \\
\hline WAZ at 3 years & $-0.5 \pm 1.2$ & $-1.2 \pm 0.9$ & $0.8 \pm 1.0$ & $<0.0001$ & $0.3 \pm 0.9$ & $-1.2 \pm 0.8$ & $<0.0001$ \\
\hline $\mathrm{WHZ}$ at 3 years & $0.9 \pm 1.3$ & $0.7 \pm 1.2$ & $1.0 \pm 1.3$ & 0.067 & $1.8 \pm 1.0$ & $0.1 \pm 0.7$ & $<0.0001$ \\
\hline
\end{tabular}

BMI - body mass index; HAZ - height-for-age Z-score; WAZ - weight-for-age Z-score; WHZ - weight-for-height Z-score.

* Student $t$-test for differences between stunted versus non-stunted children, overweight and obese versus normal-weight children.

\section{Overweight in the children}

Using the reference values of the $\mathrm{IOTF}^{25}$ it was found that $46 \%$ of the children were overweight and obese. A large proportion of these children (40\%) were also stunted.

As seen in Table 2, there were more people living in the households of the overweight compared with the normalweight children $(P=0.044)$. The overweight children's anthropometric measurements were significantly different from those of the normal-weight children except for birth length, birth and 1-year Ponderal Index; and length and $\mathrm{HAZ}$ at 3 years of age (Table 2 ).

When comparing overweight children with normalweight children, a smaller proportion of the overweight children were wasted at birth (27\% vs. $57 \% ; P<0.0001)$; stunted at 1 year (26\% vs. $41 \% ; P=0.013)$; underweight at 1 year ( $6 \%$ vs. $16 \% ; P=0.019)$; and had siblings ( $14 \%$ vs. $26 \% ; P=0.038)$. A higher proportion of overweight children had a working mother ( $23 \%$ vs. $13 \% ; P=0.063$ ) and were mainly from households of greater household density (34\% vs. $20 \% ; P=0.027$ ) compared with normalweight children.

Children having a low WHZ at birth were six times more likely to be overweight at 3 years of age, while those with a higher weight at 1 year were seven times more likely to be overweight at 3 years of age. Having an employed mother was also a risk factor for being overweight in children. It was three times higher if the mother worked or was a student. However, the risk was increased to six-fold if the mother was younger than 20 years old and eight-fold higher if the mother was the primary caregiver. Children who attained a greater length by 1 year and saw the mother daily were less likely to be overweight at 3 years of age (Table 3).

\section{Various nutritional states of the children}

From the multinomial regression analysis, being stunted was associated with having a mother who was a student, while attaining greater length at 1 year was a protective factor. Having a working mother and being overweight at 1 year were risk factors for being overweight at 3 years. On the other hand, being stunted and overweight was associated with having a large number of individuals in the household; having a mother who was employed or a student; and having a greater weight at 1 year. The only factor found to be protective against stunting and overweight was having a greater length at 1 year (Table 4).

\section{Catch-up growth}

The study also considered children who showed either catch-up or catch-down growth for both weight and length from birth (Table 5). No significant gender differences were observed in the children with respect to the various growth patterns followed.

With respect to the change in SD scores for HAZ, a high proportion of children who showed catch-down growth between birth and 1 year had no electricity in the home $\left(\chi^{2}=3.76, P=0.001\right)$ and were born to older mothers $\left(\chi^{2}=10.10, P=0.039\right)$. Catch-down growth between 1 and 3 years was associated with lack of electricity $\left(\chi^{2}=6.39, P=0.041\right)$ in addition to more individuals in the household $\left(\chi^{2}=9.25, P=0.05\right)$, being born to a mother with low parity (i.e. three children or less) 
Table 3 Binary logistic regression analysis on both stunted and overweight children at age 3 years: odds ratio (95\% confidence interval)

\begin{tabular}{|c|c|c|}
\hline Parameter & Stunted $(n=47)$ & Overweight $(n=43)$ \\
\hline Birth weight & $0.77(0.16-3.65)$ & $3.24(0.87-8.96)$ \\
\hline Birth length & $0.87(0.21-5.21)$ & $0.83(0.24-3.28)$ \\
\hline Birth Ponderal Index & $1.08(0.96-1.21)$ & $0.95(0.82-1.09)$ \\
\hline \multicolumn{3}{|l|}{ Birth HAZ } \\
\hline$<-2 S D$ & $0.55(0.13-2.39)$ & $4.03(0.12-14.2)$ \\
\hline Normal & 1.00 & 1.00 \\
\hline \multicolumn{3}{|l|}{ Birth WHZ } \\
\hline$<-2 \mathrm{SD}$ & $0.73(0.24-2.22)$ & $5.93(1.82-9.38)$ \\
\hline Normal & 1.00 & 1.00 \\
\hline 1-year weight & $3.06(0.45-8.01)$ & $6.92(2.03-16.23)$ \\
\hline 1-year length & $0.71(0.59-0.84)$ & $0.25(0.06-0.97)$ \\
\hline 1-year Ponderal Index & $0.81(0.69-0.95)$ & $0.29(0.08-1.08)$ \\
\hline \multicolumn{3}{|l|}{ 1-year HAZ } \\
\hline$<-2 \mathrm{SD}$ & $2.00(0.50-8.11)$ & $1.32(0.23-7.78)$ \\
\hline Normal & 1.00 & 1.00 \\
\hline \multicolumn{3}{|l|}{ 1-year WHZ } \\
\hline$>2 S D$ & $0.25(0.04-1.57)$ & $4.28(0.38-7.92)$ \\
\hline Normal & 1.00 & 1.00 \\
\hline \multicolumn{3}{|l|}{ Stunted at 3 years } \\
\hline Yes & & $0.64(0.19-2.16)$ \\
\hline No & & 1.00 \\
\hline \multicolumn{3}{|l|}{ Overweight at 3 years } \\
\hline Yes & $1.91(0.69-5.33)$ & \\
\hline No & 1.00 & \\
\hline \multicolumn{3}{|l|}{ Maternal age } \\
\hline$<20$ years & $0.72(0.18-2.88)$ & $6.17(1.41-7.13)$ \\
\hline$>30$ years & $0.71(0.18-2.79)$ & $1.87(0.56-6.24)$ \\
\hline $20-29$ years & 1.00 & 1.00 \\
\hline Maternal length & $0.60(0.24-4.35)$ & $2.65(0.61-5.32)$ \\
\hline \multicolumn{3}{|l|}{ Parity } \\
\hline $4+$ & $1.60(0.54-4.71)$ & $0.77(0.17-3.51)$ \\
\hline $0-3$ & 1.00 & 1.00 \\
\hline \multicolumn{3}{|l|}{ Marital status } \\
\hline Married & $0.66(0.20-2.19)$ & $1.13(0.21-6.21)$ \\
\hline Single & 1.00 & 1.00 \\
\hline \multicolumn{3}{|l|}{ Maternal education } \\
\hline Primary & $1.69(0.31-9.31)$ & $0.97(0.16-6.04)$ \\
\hline Secondary and higher & 1.00 & 1.00 \\
\hline \multicolumn{3}{|l|}{ Maternal occupation } \\
\hline Working & $3.83(0.93-5.74)$ & $3.35(2.88-9.06)$ \\
\hline Student & $3.87(1.16-12.87)$ & $3.61(0.63-7.57)$ \\
\hline Unemployed & 1.00 & 1.00 \\
\hline \multicolumn{3}{|l|}{ Main caregiver } \\
\hline Mother & $1.03(0.21-4.92)$ & $8.13(1.23-13.94)$ \\
\hline Other & 1.00 & 1.00 \\
\hline \multicolumn{3}{|l|}{ House type } \\
\hline Brick & $0.89(0.27-3.01)$ & $0.52(0.14-1.19)$ \\
\hline Other & 1.00 & 1.00 \\
\hline \multicolumn{3}{|l|}{ No. in household } \\
\hline $5-8$ & $3.06(0.71-13.24)$ & $0.92(0.14-5.93)$ \\
\hline $9+$ & $8.43(1.64-13.21)$ & $1.61(0.20-12.72)$ \\
\hline $0-4$ & 1.00 & 1.00 \\
\hline \multicolumn{3}{|c|}{ No. of children aged $<5$ years } \\
\hline $3+$ & $1.06(0.22-5.15)$ & $2.62(0.63-10.85)$ \\
\hline $0-2$ & 1.00 & 1.00 \\
\hline \multicolumn{3}{|l|}{ Child sees mother daily } \\
\hline Yes & $0.62(0.07-5.79)$ & $0.03(0.002-0.54)$ \\
\hline No & 1.00 & 1.00 \\
\hline \multicolumn{3}{|l|}{ Father in same household } \\
\hline Yes & $0.44(0.07-2.79)$ & $1.13(0.31-4.12)$ \\
\hline No & 1.00 & 1.00 \\
\hline
\end{tabular}

HAZ - height-for-age Z-score; SD - standard deviation; WHZ - weightfor-height $Z$-score.

$\left(\chi^{2}=8.91, P=0.012\right)$ and being overweight at 3 years $\left(\chi^{2}=6.39, P=0.041\right)$.

With respect to change in SD scores for WHZ, a high proportion of children who showed catch-up growth between birth and 1 year were born to older mothers ( $\left.\chi^{2}=11.80, P=0.019\right)$. Catch-down growth between 1 and 3 years was associated with households having electricity $\left(\chi^{2}=7.54, P=0.023\right)$, while in those who showed catch-up from birth to 1 years, most were born to mothers with low parity (i.e. three children or less) $\left(\chi^{2}=6.08, P=0.048\right)$.

\section{Discussion}

The major findings of this study were that: (1) half of the children were stunted (48\%), whereas less than 10\% were underweight and few were wasted; (2) just under half were overweight (22\%) and obese (24\%); and (3) just under a fifth were both overweight and stunted (19\%). The frequency of stunting reported herein is considerably higher than the national rates in children aged $1-3$ years as well as rates reported for Limpopo Province in which this study took place $^{29}$. This finding may imply a greater degree of poverty with poorer infrastructure in the study region than in other regions of South Africa. As stunting was already present in $35 \%$ of the study children at 1 year of age ${ }^{15}$, the mechanisms underlying this are more likely to be chronic than acute.

The highest risk for stunting amongst the sociodemographic factors evaluated was household size, suggesting that there is more competition for available food when the household is large $\mathrm{e}^{30}$. Another factor which conferred a high risk was having a student mother, which may be explained by the resulting reduced family income and individual care and attention given to the child, as he/she has to be left with another carer during the day ${ }^{31}$. The congruence of these findings with previous reports $8,9,32$ highlights their relevance to the development of stunting in developing countries. Assessment of length at 1 year of age may be important for health providers since this can be used to identify stunted children.

In common with other studies, the stunted children in this cohort had significantly shorter mothers than those who were not stunted ${ }^{5,8,10}$. Although this may constitute an underlying genetic factor, it is more likely that the intergenerational effect reflects long-standing maternal undernutrition and possibly even maternal restraint to growth during their own in utero period.

A relatively small proportion of the stunted children (17\%) were underweight, whilst 31\% were overweight when defined by WHZ > 1SD and 46\% when using the IOTF cut-offs ${ }^{25}$, implying that stunting is associated with both under- and overnutrition. Indeed the high prevalence of overweight associated with stunting raises many questions about the aetiology and outcomes of both under- and overnutrition. The phenomenon of childhood obesity accompanying stunting has been reported in other developing countries as well as in developed ones ${ }^{13,33}$.

The observation in this cohort that just under half of the children were overweight and/or obese is of great concern. Despite the prevalence of overweight being 
Table 4 Multinomial logistic regression of some risk factors on child nutritional status: odds ratio ( $95 \%$ confidence interval)

\begin{tabular}{|c|c|c|c|}
\hline Parameter & Stunted $(n=47)$ & Overweight $(n=43)$ & Overweight and stunted $(n=31)$ \\
\hline Birth WHZ & $0.81(0.22-3.05)$ & $0.37(0.09-1.57)$ & $0.59(0.13-2.74)$ \\
\hline 1-year weight & $3.71(0.48-8.37)$ & $2.39(1.96-4.18)$ & $8.97(1.09-13.51)$ \\
\hline 1-year length & $0.41(0.17-0.97)$ & $0.53(0.09-3.15)$ & $0.14(0.02-0.87)$ \\
\hline 1-year Ponderal Index & $0.52(0.24-1.10)$ & $0.72(0.13-3.95)$ & $0.21(0.04-1.08)$ \\
\hline \multicolumn{4}{|l|}{ Maternal age } \\
\hline$<20$ years & $0.65(0.09-4.41)$ & $2.20(0.34-14.29)$ & $1.04(0.13-8.56)$ \\
\hline$>30$ years & $0.79(0.19-3.22)$ & $0.45(0.09-2.23)$ & $0.83(0.16-4.40)$ \\
\hline $20-29$ years & 1.00 & 1.00 & 1.00 \\
\hline \multicolumn{4}{|l|}{ Maternal occupation } \\
\hline Working & $3.23(0.46-5.42)$ & 17.87 (8.24-38.78) & $10.97(1.41-14.89)$ \\
\hline Student & $18.21(9.46-34.74)$ & $4.13(0.39-9.89)$ & $7.45(3.20-17.34)$ \\
\hline Unemployed & 1.00 & 1.00 & 1.00 \\
\hline \multicolumn{4}{|l|}{ Main caregiver } \\
\hline Mother & $0.93(0.11-8.31$ & $3.74(0.29-8.71)$ & $4.43(0.38-15.34)$ \\
\hline Other & 1.00 & 1.00 & 1.00 \\
\hline \multicolumn{4}{|l|}{ Household size } \\
\hline $5-8$ & $3.64(0.46-8.74)$ & $5.35(0.72-9.81)$ & $5.23(0.31-8.69)$ \\
\hline $9+$ & $6.95(0.62-18.12)$ & $7.61(0.70-12.21)$ & $5.72(2.70-12.10)$ \\
\hline $0-4$ & 1.00 & 1.00 & 1.00 \\
\hline \multicolumn{4}{|l|}{ Child sees mother daily } \\
\hline Yes & $0.05(0.01-2.81)$ & $0.19(0.02-0.38)$ & $0.08(0.01-4.57)$ \\
\hline No & 1.00 & 1.00 & 1.00 \\
\hline
\end{tabular}

WHZ - weight-for-height Z-score.

Table 5 Percentage of children by change in standard deviation (SD) score at various time frames

\begin{tabular}{cccc}
\hline & \multicolumn{3}{c}{ Change in SD score } \\
\cline { 2 - 4 } & Catch-up & No change & Catch-down \\
\hline HAZ & & & \\
$0-1$ years & 16.5 & 25.2 & 58.3 \\
1-3 years & 13.1 & 41.5 & 45.4 \\
$0-3$ years & 4.2 & 29.2 & 66.7 \\
WHZ & & & \\
$0-1$ years & 74.1 & 17.3 & 7.9 \\
$1-3$ years & 44.6 & 37.7 & 17.7 \\
$0-3$ years & 80.6 & 14.6 & 4.9 \\
\hline
\end{tabular}

HAZ - height-for-age Z-score; WHZ - weight-for-height $Z$-score.

comparable to that of other developing countries, the obesity levels are higher ${ }^{34}$, even in comparison with other studies in South African children, which range from 7.5 to $20.1 \%{ }^{16,21}$. The wide variation in South African prevalence rates is possibly due to inequalities in socio-economic status, since it has been shown that some provinces, including Limpopo, are amongst the poorest. Limpopo Province has a high prevalence of illiteracy, high rates of unemployment, poor sanitation facilities, low levels of electrification and high household density, which have all been documented as being related to stunting ${ }^{35}$.

Previous research has shown that overweight is an outcome of sociodemographic status, maternal feeding practices and cultural beliefs as to what is normal $1^{1,9,36-39}$. 'Young' mothers, 'working' mothers and 'primary caregiver' mothers all conferred an increased risk for having an overweight child. However, having a working mother was the only factor that remained significantly associated with overweight in the multinomial analysis, thus emphasising the likely importance of increased family income and subsequent food availability for the child in the development of overweight in this setting ${ }^{40,41}$.

Previous studies on feeding practices have reported a dose-dependent protective effect of breast milk against obesity. Although most children in the present study were breast-fed for a year or more, a phenomenon well documented in South Africa ${ }^{19,42,43}$, only $10 \%$ of the children in this cohort were exclusively breast-fed for the first 3 months of life and $4 \%$ for 6 months ${ }^{15}$; hence it is difficult to comment on the role of exclusive breastfeeding in the aetiology of overweight and/or obesity. However, the majority of infants in this study were introduced to complementary foods at a very early age (between 0 and 3 months). Most of these foods were high in energy and carbohydrates and poor in protein and essential nutrients required for linear growth. Hence it is possible to understand why obesity and stunting could be the outcomes ${ }^{15,18,42,44}$.

Baughcum et ll $^{37}$ reported that a high percentage of mothers with a poor education did not consider their overweight children to be overweight. It is believed that mothers have their own culturally based and influenced definitions of obesity ${ }^{36}$. Thus with the cultural belief that 'bigger is healthier' in the Pedi group studied ${ }^{36,38}$, the mother of a lean healthy baby might feel that her child is not getting sufficient food and, as such, change her feeding practices. This may result in her overfeeding the child, a phenomenon also reported by Kagamimori et al. ${ }^{45}$.

As opposed to adults, where obesity is an immediate risk factor for most chronic diseases, in children it rarely poses an immediate and serious health threat. In effect, its short-term consequences are often psychosocial and include outcomes such as low self-esteem, poor peer acceptance and low participation in social and sporting 
activities $^{46}$. Available evidence suggests that the influence of childhood obesity on adult status rises with age, with a low predictive value in children below 2 years of age, a significant predictor at 3-5 years, and an even a stronger one at older ages ${ }^{47,48}$.

The risk factors for the coexistence of stunting and overweight in the children in this study were having an increased weight and shorter length at 1 year, having more than nine persons in the household, and having a working mother or a mother who was a student. The association with increased weight and shorter length is likely due to the quality of the diet consumed (rich in carbohydrates and poor in proteins $)^{18,43,44,49,50}$. It is likely that the children have a sub-minimum protein intake, which results in failure of linear growth and the high stunting levels already evident at 1 year. Should the diet subsequently remain a high-energy, high-carbohydrate one, it is likely that excess weight gain will take place in addition to sub-optimal linear growth; with the latter still not being optimal.

The seemingly contradictory association between maternal occupation and the combination of stunting and overweight is likely due to an oversimplification of the interrelationship between the various demographic and household factors studied as markers of poverty.

According to Dietz ${ }^{51}$, there are four 'critical periods' for development of obesity in children: gestation, early infancy, period of adiposity rebound (5-7 years) and adolescence. However, it has been shown that the age group $0-3$ years is the most vulnerable to stunting, which may increase risks of being overweight later in life ${ }^{15,16,41,52}$. Catch-up (catch-down) growth is a phenomenon characterised by an increased (decreased) growth velocity in height and/or weight following the removal (addition) of some constraints on normal growth. Rapid catch-up growth in weight during infancy has been linked to risk factors for overweight and obesity ${ }^{26,53,54}$. We have previously shown that stunting and overweight in this group of children starts from an early age, $0-1$ year $^{15}$.

The results from this study highlight the importance of evaluating anthropometric status in terms of both stunting and overweight as well as the combination of these two factors. In the past the focus has been on one or the other and the combination has remained largely uninvestigated. It is important that healthcare providers realise the importance of normal weight and length being attained at 1 year of age, since these in turn predict nutritional status at 3 years of age.

\section{Acknowledgements}

This study was supported by grants from the Institute for Research in Extramural Medicine (EMGO), Vrije University, Amsterdam (The Netherlands). We would like to thank Ms MA Makwela and Mr RP Mamabolo (fieldworkers), and also the nursing staff at the nine clinics, for their assistance in conducting this study.

\section{References}

1 Frongillo EA Jr, de Onis M, Hanson KMP. Socioeconomic and demographic factors are associated with worldwide patterns of stunting and wasting of children. Journal of Nutrition 1997; 127: 2302-9.

2 Bourne LT, Lambert EV, Steyn K. Where does the black population of South Africa stand on the nutrition transition? Public Health Nutrition 2001; 5: 157-62.

3 Monteiro CA, Conde WL, Popkin BM. Is obesity replacing or adding to undernutrition? Evidence from different social classes in Brazil. Public Health Nutrition 2002; 5: 105-12.

4 Adair LS, Guilkey DK. Age specific determinants of stunting in Filipino children. Journal of Nutrition 1997; 127: 314-20.

5 Saleemi MA, Ashraf RN, Mellander L, Zaman S. Determinants of stunting at 6,12, 24 and 60 months and postnatal linear growth in Pakistani children. Acta Paediatrica 2001; 90 : 1304-8.

6 Vella V, Tomkins A, Borghesi A, Migliori GB, Oryem VY. Determinants of stunting and recovery from stunting in Northwest Uganda. International Journal of Epidemiology 1994; 23: 782-6.

7 Zamiliah MM, Kandian M, Lin KG, Siong TE. Socioeconomic profile and nutritional status of children in rubber smallholdings. Asia Pacific Journal of Clinical Nutrition 2002; 11: 133-41.

8 Delpeuch F, Traissac P, Martin-Prevel Y, Massamba JP, Maire B. Economic crisis and malnutrition: socioeconomic determinants of anthropometric status of preschool children and their mothers in an African urban area. Public Health Nutrition 2000; 3: 39-47.

9 Ukwuani FA, Suchindran CM. Implications of women's work for child nutritional status in sub-Saharan Africa: a case study of Nigeria. Social Science \& Medicine 2003; 56: 2109-21.

10 Hernandez-Diaz S, Peterson KE, Dixit S, Hernandez B, Parra S, Barquera S, et al. Association of maternal short stature with stunting in Mexican children: common genes vs common environment. European Journal of Clinical Nutrition 1999; 53: 938-45.

11 de Onis M, Frongillo EA, Blossner M. Is malnutrition declining? An analysis of changes in levels of child malnutrition since 1980. Bulletin of the World Health Organization 2000; 78: 1222-33.

12 Hautvast JLA, Tolboom JJM, Kafwembe EM, Musonda RM, Mwanakasale V, van Staveren WA, et al. Severe linear growth retardation in rural Zambian children: the influence of biological variables. American Journal of Clinical Nutrition 2000; 71: 550-9.

13 Faber M, Jogessar VB, Benade AJS. Nutritional status and dietary intakes of children aged $2-5$ years and their caregivers in a rural South African community. International Journal of Food Sciences and Nutrition 2001; 52: 401-11.

14 Monyeki KD, van Lenthe FJ, Steyn NP. Obesity; does it occur in African children in a rural community in South Africa? International Journal of Epidemiology 1999; 28: 287-92.

15 Mamabolo RL, Alberts M, Mbenyane GX, Steyn NP, Nthangeni NG, Delemarre-van de Waal HA, et al. Feeding practices and growth of infants from birth to 12 months in the central region of the Limpopo Province of South Africa. Nutrition 2004; 20: 327-33.

16 Steyn NP, Labadarios D, Maunder E, Nel J, Lombard C; Directors of the National Food Consumption Survey. Secondary anthropometric data analysis of the National Food Consumption Survey in South Africa: the double burden. Nutrition 2005; 21: 4-13.

17 Patel DN, Pettifor JM. Malnutrition in South Africa. South African Journal of Food Science and Nutrition 1992; 4: 22 . 
18 Steyn NP, Badenhorst CJ, Nel JH, Ladzani R. Breast-feeding and weaning practices of Pedi mothers and the dietary intakes of their preschool children. South African Journal of Food Science and Nutrition 1993; 5: 10-13.

19 Dannhauser A, Bester CJ, Joubert G, Badenhorst PN, Slabber M, Badenhorst AM, et al. Nutritional status of preschool children in informal settlement areas near Bloemfontein, South Africa. Public Health Nutrition 2000; 3: 303-12.

20 Fourie J, Steyn K. Chronic Diseases of Lifestyle in South Africa. MRC Technical Report. Cape Town: Medical Research Council, 1995.

21 Bourne LT, Langenhoven ML, Steyn K, Jooste PL, Laubscher JA, Bourne DE. Nutritional status of 3-6 year-old children in the Cape Peninsula. The BRISK Study. East African Medical Journal 1994; 7: 695-702.

22 Yanovski JA, Yanovski SZ. Treatment of pediatric and adolescent obesity. Journal of the American Medical Association 2003; 289: 1851-3.

23 Mamabolo RL, Alberts M, Steyn NP, Delemarre-van de Waal HA, Nthangeni NG, Levitt NS. Evaluation of the effectiveness of iron and folate supplementation during pregnancy in a rural area of Limpopo province. South African Journal of Clinical Nutrition 2004; 17: 15-21.

24 Hamill PV, Dritz TA, Johnson CL, Reed RB, Roche AF. NCHS Growth Curves for Children Birth-18 years. DEHW Publications No. (PHS) 78-1650, Series 11, No. 165 Washington, DC: DEHW Publishers, 1977.

25 Cole TJ, Bellizzi MC, Flegal KM, Dietz WH. Establishing a standard definition for child overweight and obesity worldwide: international survey. British Medical Journal 2000; 320: 1-6.

26 Ong KK, Ahmed ML, Emmett PM, Preece MA, Dunger DB, The ALSPAC Study Team. Association between postnatal catch-up growth and obesity in childhood: prospective cohort study. British Medical Journal 2000; 320: $967-71$

27 Centers for Disease Control and Prevention (CDC). Epi-Info 2002, A Database and Statistics Program for Public Health Professionals. Atlanta, GA: CDC, 2003.

28 SPSS Inc. SPSS for Windows Base System User's Guide, Release 12.0. Chicago, IL: SPSS Inc., 2003.

29 Labadarios D, Steyn N, Maunder E, MacIntyre U, Swart R, Gericke G, et al. The National Food Consumption Survey (NFCS): Children aged 1-9 years, South Africa, 1999. Stellenbosch: Stellenbosch University Press, 2000.

30 James WPT, Ferro-Luzzi A, Sette S, Mascie-Taylor CGN. The potential use of maternal size in priority setting when combating childhood malnutrition. European Journal of Clinical Nutrition 1999; 53: 112-9.

31 Lei DLM, Chaves SP, Paes AT, Escuder MM, Ribeiro AB, Freire $\mathrm{RD}$, et al. Risk of linear growth retardation during the first two years of life: a new approach. European Journal of Clinical Nutrition 1999; 53: 456-60.

32 Shah SM, Selwyn BJ, Luby S, Merchant A, Bano R. Prevalence and correlates of stunting among children in rural Pakistan. Pediatrics International 2003; 45: 49-53.

33 Sanchez-Castillo CP, Lara JL, Villa AR, Aguirre J, Escobar M, Gutierrez H, et al. Unusually high prevalence rates of obesity in four Mexican rural communities. European Journal of Clinical Nutrition 2001; 55: 833-40.

34 Martorell R, Khan LK, Hughes ML, Grummer-Strawn LM. Overweight and obesity in preschool children from developing countries. International Journal of Obesity and Related Metabolic Disorders 2001; 24: 959-67.

35 Zere E, McIntyre D. Inequities in under-five child malnutrition in South Africa. International Journal for Equity in Health 2003; 2 : 7.

36 Baughcum AE, Powers SW, Johnson SB, Chamberlin LA, Deeks CM, Jain A, et al. Maternal feeding practices and beliefs and their relationships to overweight in early childhood. Journal of Developmental and Behavioral Pediatrics 2001; 22: 391-408.

37 Baughcum AE, Chamberlin LA, Deeks CM, Powers SW, Whitaker RC. Maternal perceptions of overweight preschool children. Pediatrics 2000; 106: 1380-5.

38 Kruger R, Gericke GJ. A qualitative exploration of rural feeding and weaning practices, knowledge and attitudes on nutrition. Public Health Nutrition 2003; 6: 217-23.

39 Faith MS, Keller KL, Matz P, Johnson SL, Lewis R, Jorge MA, et al. Project Grow-2-Gether: a study of the genetic and environmental influences on child eating and obesity. Twin Research 2002; 5: 472-5.

40 Engel PL. Influences of mother's and father's income on child's nutritional status in Guatemala. Social Science $\mathcal{E}$ Medicine 1993; 37: 1303-12.

41 Popkin B, Richards M, Monteiro C. Stunting is associated with overweight in children of four nations that are undergoing the nutrition transition. Journal of Nutrition 1996; 126: 3009-16.

42 Delport SD, Becker PJ, Bergh A. Growth, feeding practices and infections in black infants. South African Medical Journal 1997; 87: 57-61.

43 Steyn NP, Nel JH, Kunnene E, Tichelaar HY, Oelofse A, Prinsloo JF, et al. Differences between underweight and normal weight rural preschool children in terms of infant feeding practices and socio-economic factors. South African Medical Journal 1998; 5: 641-6.

44 Ladzani R, Steyn NP, Nel JH. Infant feeding practices of Pedi women in six semi-rural areas of Northern Province. South African Journal of Epidemiology and Infection 1998; 13: $63-5$.

45 Kagamimori S, Yamagami T, Sokejima S, Numata N, Handa K, Nanri S, et al. The relationship between lifestyle, social characteristics and obesity in 3-year-old Japanese children. Child: Care, Health and Development 1999; 25: 235-46.

46 Dietz WH. Health consequences of obesity in youth: childhood predictors of adult disease. Pediatrics 1998; 101: $518-25$.

47 Serdula MK, Ivery D, Coates RJ, Freedman DS, Williamson DF, Byers T. Do obese children become obese adults? A review of the literature. Preventive Medicine 1993; 22 $167-77$.

48 Whitaker RC, Wright JA, Pepe MS, Siedel KD, Dietz WH. Predicting obesity in young adulthood from childhood and parental obesity. New England Journal of Medicine 1997; 337: 869-73.

49 Steyn NP, Badenhorst CJ, Nel JH. The nutritional status of Pedi preschool children in two rural areas of Lebowa. South African Journal of Food Science Nutrition 1992; 4: 24-8.

50 Badenhorst CJ, Steyn NP, Jooste PL. Nutritional status of Pedi school children aged 6-14 years in two rural areas in Lebowa: a comprehensive nutritional survey of dietary intake, anthropometric and clinical measurements. South African Journal of Food Science and Nutrition 1993; 5: $112-5$

51 Dietz WH. Critical periods in childhood for the development of obesity. American Journal of Clinical Nutrition 1994; 59: 955-9.

52 Popkin BM. The nutrition transition and obesity in the developing world. Journal of Nutrition 2001; 131: 871S-3S.

53 Law CM, Shiell AW, Newsome CA, Syddall HE, Shinebourne EA, Fayers PM, et al. Fetal, infant, and chzildhood growth and adult blood pressure: a longitudinal study from birth to 22 years of age. Circulation 2002; 105: 1088-92.

54 Cameron N, Pettifor J, De Wet T, Norris S. The relationship of rapid weight gain in infancy to obesity and skeletal maturity in childhood. Obesity Research 2003; 1: 457-60. 